\title{
Chemical Proteomics-Based Analysis of Off-target Binding Profiles for Rosiglitazone and Pioglitazone: Clues for Assessing Potential for Cardiotoxicity
}

\author{
Brian R. Hoffmann ${ }^{1,{ }^{*}, \text { Mohamed F. El-Mansy }^{2} \text {, Daniel S. Sem }}{ }^{2,3}$, and Andrew S. Greene ${ }^{1}$ \\ ${ }^{1}$ Biotechnology and Bioengineering Center, Medical College of Wisconsin, Milwaukee, WI 53226 \\ ${ }^{2}$ Chemical Proteomics Facility at Marquette, Department of Chemistry, Marquette University, \\ Milwaukee, WI 53201
}

\begin{abstract}
Drugs typically exert desired and undesired biological effects by virtue of binding interactions with protein target(s) and off-target(s), providing evidence for drug efficacy and toxicity. Pioglitazone and rosiglitazone possess a common functional core, glitazone, which is considered a privileged scaffold upon which to build a drug selective for a given target - in this case PPAR $\gamma$. Herein, we report a retrospective analysis of two variants of the glitazone scaffold, pioglitazone and rosiglitazone, in an effort to identify off-target binding events in the rat heart to explain recently reported cardiovascular risk associated with the drugs. Our results suggest glitazone has affinity for dehydrogenases, consistent with known binding preferences for related rhodanine cores. Both drugs bound ion channels and modulators, with implications in congestive heart failure, arrhythmia, and peripheral edema. Additional proteins involved in glucose homeostasis, synaptic transduction, and mitochondrial energy production were detected and potentially contribute to drug efficacy and cardiotoxicity.
\end{abstract}

\section{Keywords \\ Peroxisome proliferator-activated receptor; thiazolidinediones; rosiglitazone; pioglitazone; glitazone}

\section{INTRODUCTION}

Type 2 diabetes drugs rosiglitazone and pioglitazone (Figure 1) are currently the only two thiazolidinedione-based drugs on the market in the United States and both share a common

\footnotetext{
*Corresponding Author: Brian R. Hoffmann, Biotechnology and Bioengineering Center, Medical College of Wisconsin, 8701 Watertown Plank Road, Milwaukee, WI 53226; bhoffmann@mcw.edu; Phone, 414-955-7648; Fax, 414-955-6568.

${ }^{3}$ Present address: Center for Structure-based Drug Design and Development, School of Pharmacy, Concordia University Wisconsin, Mequon, WI, 53097.

The content is solely the responsibility of the authors and does not necessarily represent the official views of the National Heart, Lung, And Blood Institute or the National Institutes of Health.

SUPPORTING INFORMATION AVAILABLE

Additional rosiglitazone and pioglitazone off-target binding profile comparison data for mass spectral proteomic analyses can be found in Supplemental Table 1. This material is available free of charge via the Internet at http://pubs.acs.org.
} 
functional glitazone core. Although the Food and Drug Administration began restricting access to rosiglitazone in the United States in November of 2011 due to increased risk of myocardial infarction no such restrictions are in place for pioglitazone. An earlier thiazolidinedione-based drug, troglitazone, was removed from the market due to hepatotoxic effects $^{1}$, but rosiglitazone and pioglitazone have not exhibited this effect, despite debate ${ }^{2,3}$.

Rosiglitazone and pioglitazone are stand alone therapy for type 2 diabetes or for use in combination with metaformin or glimedpiride. Both drugs are thought to exert their therapeutic effect via binding to peroxisome proliferator-activated receptor (PPAR $\gamma$ ) in adipose tissue ${ }^{4-7}$, leading to increase insulin sensitivity and better glycemic control. Despite their chemical and mechanistic similarities, there are large cohort studies suggesting that rosiglitazone causes peripheral edema ${ }^{8,9}$ and congestive heart failure ${ }^{10-12}$ to a greater extent than pioglitazone. On the other hand, there are additional studies suggesting that there is no increased risk of peripheral edema ${ }^{13}$ and adverse cardiovascular events ${ }^{14,15}$ between rosiglitazone in comparison to pioglitazone.

Serious concerns over cardiovascular events were first raised in 2007 as a result of a metaanalysis suggesting that rosiglitazone led to a $43 \%$ higher risk of myocardial infarction and a $64 \%$ higher risk of cardiovascular death when compared to patients receiving alternative type II diabetes treatments, not including pioglitazone ${ }^{10}$. Shortly after the 2007 metaanalysis was published, it was challenged due to its lack of heterogeneity, noting the exclusion of studies with zero events in treatment and control groups ${ }^{14,16}$. A more recent and larger cohort study of 227,571 Medicare beneficiaries (average age of 74) identified a statistically significant $0.4 \%$ increased risk for stroke and heart failure as well as "all-cause mortality" for patients treated with rosiglitazone relative to pioglitazone ${ }^{11}$. However, a study in response to the Medicare beneficiaries study was published showing there was no statistically significant difference between rosiglitazone and pioglitazone in "all-cause mortality" when 36,000 patients (average age of 54) were propensity score matched to control for variables such as age, gender, and previous history of cardiovascular problems ${ }^{15}$. Regardless, one argument is that rosiglitazone presents relatively higher cardiovascular risks, yet provides no additional therapeutic benefit, calling its utility of treating type 2 diabetes patients into question, while pioglitazone has not yet been reported to tip the benefit/risk balance. Questions as to how and if rosiglitazone may be leading to a relatively higher cardiovascular risk still remain largely unanswered. This discrepancy as to whether or not patients taking rosiglitazone run a higher risk of cardiovascular events and death than those taking pioglitazone and the underlying cause of the cardiovascular risks, led to our exploration of the off-target binding profiles.

In a previous study ${ }^{17}$, a chemical proteomic approach was presented for assessing target and anti-target (i.e. off-target) protein binding profiles for a rhodanine drug core. A similar approach is used herein to assess similarities and differences in the heart protein binding profiles between rosiglitazone and pioglitazone (Figure 1), but with more sophisticated selection techniques and computational/statistical analysis of binding profiles. As before, the common core or "privileged scaffold" - in this case glitazone - was used to create an affinity column (Figure 1), to which proteins from the target organ were bound. Rat heart tissue homogenate was used since the goal was to identify protein binding events that may be associated with direct cardiovascular risk. Proteins were eluted with the glitazone-based 
drugs rosiglitazone or pioglitazone and eluted proteins were identified using tandem mass spectrometry (MS). Similarities in binding patterns between these two elutions may suggest unknown mechanisms of action in addition to PPAR $\gamma$ binding, and possible sources of shared adverse effects. Conversely, differences may reveal direct protein complex binding events leading to the increased cardiovascular risk that may be unique to one drug or the other.

In the current study, we have used this modified highly-specific technique to make an unbiased comparison of similarities and differences between off-target molecular mechanisms that could lead to cardiotoxicity for the two major glitazone-based drugs, rosiglitazone and pioglitazone. We used a two-phase selection method in which the protein must first bind to the privileged scaffold (i.e. glitazone) on the resin and then have higher affinity for the elution compound (i.e. rosiglitazone or pioglitazone). While our original hypothesis was that there would be significant off-target protein binding profile differences, thereby explaining an increase in rosiglitazone cardiotoxicity versus pioglitazone, as suggested by some meta-analyses ${ }^{10,11}$, the data suggests that is not the case. Our results suggest that, while there is some differential protein binding, the off-target binding profiles are quite similar and the majority of proteins with potential for cardiotoxic effects did not exhibit significant differential binding in comparisons of the drugs, supporting conflicting meta-analyses stating that they contain a similar cardiotoxic risk ${ }^{15,16}$. Binding profiles obtained for these drugs suggest that the cardiotoxic effects could be a result of disruption in ion channel modulation (ex. L-type calcium channel), neuronal signaling network in the heart, or heart energy demand regulation in diabetic patients taking both rosiglitazone and pioglitazone. This may implicate the drugs in similar mechanisms of action for adverse effect reactions due to off-target binding. In addition to PPAR $\gamma$ binding as a mechanism of action, additional sources of drug efficacy may occur from off-target binding, leading to increased insulin-sensitivity. Notably, there are numerous proteins detected in rosiglitazone and pioglitazone elutions that regulate mitochondrial function, gluconeogenesis/glycolysis, and lipid metabolism.

\section{RESULTS}

\section{Assessing specificity of privilaged scaffold using affinity chromatography}

Glitazone was coupled to an epoxy resin to enable privileged scaffold-based (Figure 1) purification of target organ or tissue homogenate protein binding partners. The TZDs (thiazolidinediones) contained within the core glitazone scaffold contains the majority of binding interactions seen in crystal structures with PPAR $\gamma^{4}$ and has affinity for target, so while there is a distinct chance some proteins might be missed, the majority of interacting proteins and potential complex partners will be captured by the affinity resin. Differences seen in comparisons of rosiglitazone and pioglitazone elutions will identify proteins with selectivity for these additional drug functional components, added to the glitazone core. Reaction of the glitazone with an epoxy resin was confirmed through detection of new hydroxy peaks (-OH) in an infrared (IR) spectrum of the coupled resin (data not shown), due to opening of the epoxide ring (Figure 1). The IR spectrum indicated that glitazone was 
efficiently coupled; an additional phenol column was created using p-cresol and the epoxy resin (data not shown) for comparison.

Previous literature indicated that a rhodanine group, related to the thiazolidinedione core glitazone, exhibits high affinity for dehydrogenase enzymes in general ${ }^{17}$, so it was utilized as a test group to examine drug specificity for heart homogenate protein. Glitazone, rosiglitazone, and pioglitazone elutions all bound numerous dehydrogenase enzymes. Off of a glitazone scaffold glitazone eluted 16 dehydrogenase enzymes, rosiglitazone eluted 6 , and pioglitazone eluted 5 (Table 1), showing a higher degree of specificity obtained by the drugs compared to the core group. Suppression of dehydrogenases have also been shown to effect adipogenesis ${ }^{18,19}$, a primary effect of the drugs. Eluted proteins with higher affinity for the drugs will have an increase in peptide/scan count compared to glitazone or vice versa when normalized for total scan count, helping determine which proteins demonstrate the highest affinity for the drugs. Additionally, proteins previously shown to be affected in processing and secretion after administration of TZDs, such as cytoplasmic superoxide dismutase (SODC) (Supplemental Table 1), catalase (Supplemental Table 2), and numerous ion channels (Table 4) were found to interact with the drugs in turn relating specificity further to previous literature ${ }^{18,20-26}$.

Due to the importance of achieving high specificity with this two-phase selection purification process, protein lists were validated further to show enrichment of lower abundance binding partners, expanding the dynamic range. This validation was completed by comparing non-specific high salt elutions versus drug elutions of heart proteins, such as ion channels, off of the glitazone scaffold. For instance, the L-type calcium channel (CAC1F; rosiglitazone, $\mathrm{p}=2.15 \mathrm{e}-06$; pioglitazone, $\mathrm{p}=0.00072$ ), chloride channel protein 6 (CLCN-6; rosiglitazone, $\mathrm{p}=0.00015$; pioglitazone, 3.21e-07), and salt-incucible kinase 2 (SIK2; rosiglitazone, 4.68e-011; pioglitazone, 3.86e-10) were all significantly increased in drug versus high salt elutions off the glitazone scaffold. This enhancement of the dynamic range of detection was consistently seen across the dataset. An alternative validation was required for those highly abundant proteins that bound to glitazone and had high affinity for rosiglitazone or pioglitazone because high salt would elute these proteins in abundance off of the scaffold. Comparisons can be made between the phenol and glitazone scaffold drug elutions to validate this dataset since the glitazone should contain higher specificity for the proteins than general hydrophobic binding achieved on the phenol column. Using ATP synthase beta-chain as an example of the more abundant proteins present, there was significant enrichment by rosiglitazone $(\mathrm{p}=0.031)$ and pioglitazone $(\mathrm{p}=0.00053)$ off the glitazone versus phenol scaffolds.

\section{Total heart protein eluted off glitazone and phenol columns}

Heart protein homogenates were bound to the glitazone column and eluted off using high salt tris-buffered saline, $\mathrm{pH} 6.8$ (non-specific), $2 \mathrm{mM}$ glitazone (same as scaffold), $50 \mu \mathrm{M}$ rosiglitazone (selecting for highly specific binding), and $50 \mu \mathrm{M}$ pioglitazone (selecting for highly specific binding) elutions. Eluted proteins were prepared for orbitrap tandem MS analysis and compared against the UniprotKB rodent database. During data analysis utilizing in-house Visualize software ${ }^{27}$, technical and biological replicates were combined 
and filtered for removal of common contaminants and redundant protein/peptide hits, a $\mathrm{P} \searrow 0.85$ for the protein, and a scan count $\geq 8$ for any given protein. Total protein elution sets consisted of proteins detected from all elution conditions combined for any given column and filtered as noted above, providing a more complete list of all proteins bound. In assessing total elution sets (i.e. all elution sets combined and filtered) for both the phenol (Figure 2A) and glitazone (Figure 2B) columns, there were 349 and 222 total heart proteins respectively. Of the total protein elution dataset, rosiglitazone displayed a significant increase in 65 proteins ( 5 unique) eluted off the glitazone column and 18 proteins ( 5 unique) eluted off the phenol column compared to the total. Pioglitazone displayed a significant increase in 37 proteins ( 1 unique) eluted off the glitazone column and 23 proteins ( 7 unique) eluted off the phenol column. Only six proteins overlapped between those significantly increased with rosiglitazone on the two columns and three proteins for pioglitazone elutions, which displayed the increased specificity of the drugs for elution of proteins bound to the glitazone column. When overlapping proteins between different elution conditions in the total protein bound dataset were accounted for, there were 156 proteins bound to the glitazone column and 122 proteins bound to the phenol column not significantly increased when compared to individual drug elution conditions against the total.

Total protein bound comparisons included the most non-specific elution condition, high salt TBS at $\mathrm{pH} 6.8$, in which eluted proteins were dependent on a single selection for binding to the core compound (i.e. glitazone). However, glitazone containing compound elutions contain a second target specific selection process through addition of the compound in the elution. Comparing the non-specific single selection with the double selection protein datasets can skew the numbers, so additional comparisons were generated (Figure 3). In order to focus on scaffold-bound proteins with the highest degree of specificity for the glitazone compounds, the strategy was enhanced by focusing on protein datasets compiled by adding a target specific elution by glitazone, rosiglitazone, and pioglitazone. A three-way comparison of the glitazone containing compound elution protein datasets (filtered as described for the total protein datasets) was generated (Figure 3 ). The phenol column resulted in 101 proteins and the glitazone column in 153 proteins eluting and passing the stringent filters. This type of analysis is unique due to the two-phase selection of affinity for the compound on the resin and then a second selection for the compound used for elution. Once again, the specificity among TZD compounds off a glitazone column compared to the phenol column can be observed by the increase in bound proteins eluted off by the specific drugs during the specific two-phase selection.

\section{Direct comparison of rosiglitazone versus pioglitazone elutions off a glitazone scaffold}

Proteins bound to the glitazone scaffold and eluted with the target-specific glitazone drug contain the highest degree of specificity and were the focus henceforth. During comparison analysis of rosiglitazone and pioglitazone elutions, proteins were filtered as before, along with addition of a run count $\geq 6$ and normalization for total scan count between groups provided an expected scan count ${ }^{27}$. Comparisons were then separated into five main categories: 1) Unique to rosiglitazone elutions, 2) unique to pioglitazone elutions, 3) significantly increased in rosiglitazone elutions, 4) significantly increase in pioglitazone elutions, and 5) not significantly different between the drugs. In direct comparisons of the 
proteins eluted off the glitazone scaffold by rosiglitazone or pioglitazone, there were more similarities than differences. Many of the proteins that were significantly increased with rosiglitazone or pioglitzone in comparisons were still abundant in the elutions resulting from both drugs. Altogether, 92 heart proteins passed the appropriate filters for the comparison of rosiglitazone to pioglitazone (Supplemental Table 1). Of the 92 proteins present in the direct protein binding comparison dataset between rosiglitazone and pioglitazone, 67\% (62 proteins) were not significantly different. Only $6.5 \%$ (6 proteins) were unique to rosiglitazone and $6.5 \%$ (6 proteins) unique to pioglitazone (Table 2$)$. There were $11 \%$ (10 proteins) and $8.7 \%$ (8 proteins) significantly increased in rosiglitazone and pioglitazone elutions, respectively (Table 3 ). Since there were few unique differences between rosiglitazone and pioglitazone, we further assessed the dataset by examining those heart proteins that were significantly increased in abundance $(\mathrm{P} \unlhd(05)$ in elutions by one drug versus the other because those proteins are candidates to explain mechanistic differences that could result in impaired cardiac function. While rosiglitazone elutions contained 10 proteins that were significantly increased compared to pioglitazone, the fold change was much less drastic than the 8 proteins significantly increased by pioglitazone elution (Table 3). The list of proteins in Tables 2 and 3 only indicate slight differences in rosiglitazone versus pioglitazone elutions and the proteins fall in similar mechanistic pathways to those not significantly different between the drugs, indicating they are potentially affecting the same biological processes. Altogether, both drugs contained off-target binding partners involved in ion transport modulation (Table 4) and neuronal networks (Table 5), which could have potential impact on heart muscle contraction. Additionally, proteins involved in the gluconeogenesis/glycolysis cycle, long-chain fatty acid uptake, transport between the mitochondria and cytoplasm, amino acid metabolism, and energy transduction were identified (Tables 1-5 and Supplemental Table 1).

\section{Heart off-target protein binding profile trends for rosiglitazone and pioglitazone elutions}

Since the majority of off-target binding partners for both rosiglitazone and pioglitazone are similar, further analysis of the 92 protein comparison dataset focused on exploring directly affected pathways or classes of proteins shared between rosiglitazone and pioglitazone elutions. There were 10 ion channels or channel regulators detected at a similar abundance for rosiglitazone and pioglitazone, including regulators of small amine, calcium, chloride, sodium, and electron transport (Table 4). Identified were a voltage-dependent L-type calcium channel, a calcium channel regulator FAK2, mitochondrial adenosine triphosphatases (ATPases), and various modulators of sodium and chloride transport. L-type calcium channels have a central role in cardiac function, include effects on cardian arrhythmias. Only the membrane transport protein XK $(\mathrm{p}=0.0024)$ and modulator of $\mathrm{Na}, \mathrm{K}-$ ATPase ( $\mathrm{p}=0.014$ ) were significantly increased in rosiglitazone elutions and trace amineassociated receptor $7 \mathrm{~b}(\mathrm{p}=1.83 \mathrm{e}-5)$ in pioglitazone elutions. Interestingly, numerous modulators of amine transport not only are linked to cardiovascular function, but also neurotransmitter regulation and excitable synaptic transmission.

Numerous proteins within the rosiglitazone and pioglitazone comparison were also implicated in neuronal function and excitatory synaptic transmission. Not including the channels mentioned above, there were 16 proteins in the rosiglitazone and pioglitazone 
comparison that mediate neuronal functions (Table 5). Cardiotropin-like cytokine factor 1 ( $\mathrm{p}=0.012$ ), nerofibromin $(\mathrm{p}=0.046)$, and Ras GTPase-activating SynGAP $(\mathrm{p}=7.32 \mathrm{e}-4)$ were significantly increased in rosiglitazone elutions and norrin $(\mathrm{p}=4.05 \mathrm{e}-17)$ plus PACSN2 $(\mathrm{p}=1.27 \mathrm{e}-5)$ were unique. The other 11 proteins implicated in synaptic transmission were not significantly different between the drugs. To determine if the ion channels, channel modulators, and synaptic transmission regulators were in unique networks to the heart and not a general network of proteins throughout the body we compared the heart elution profiles of rosiglitazone and pioglitazone to liver off-target binding profiles (data not shown) generated in the same manner as with the heart Tables 4 and 5. Proteins identified in Tables 4 and 5 were found to be unique or significantly increased in the heart elution dataset versus the liver, suggesting the drugs bind a unique set of ion/amine channels and neuronal excitatory network in the heart.

Rosiglitazone and pioglitazone have been shown to bind purified PPAR $\gamma$ with high affinity in purified samples and have been indirectly shown to activate the PPAR $\gamma$ pathway 4, 6, 7; target organs in vivo are adipose and liver. However, it is unclear if this direct PPAR $\gamma$ interaction would occur in the rat heart. In exploring the tandem MS datasets from rosiglitazone and pioglitazone heart protein elutions off of the glitazone scaffold, there was no PPAR $\gamma$ detection. To assess whether the expression was too low in the heart for detection, the glitazone column elution experiments were repeated by substituting fatty rat liver tissue homogenates in place of those generated from the heart. PPAR $\gamma$ was detected minimally in rosiglitazone (1 peptide/4 scans) but not in pioglitazone elutions off the glitazone column. On the other hand, PPAR $\delta$ was detected in both rosiglitazone (1 peptide/3 scans) and pioglitazone (1 peptide/10 scans) elutions of liver protein off the glitazone column. Given the low expression levels of transcription factors, it is expected that PPAR detection would be challenging via MS even if present in elutions due to the presence of the more abundant proteins. Among proteins detected in rosiglitazone and pioglitazone elutions off of the glitazone column, there were 22 involved in fatty acid metabolism, tricarboxylic acid metabolism, glycolysis/gluconeogenesis, and insulin signaling pathway regulation (Supplemental Table I). Within these processes mitochondrial respiration, the Citric Acid (TCA) Cycle, and energy regulation were implicated. The salt-inducible kinase 2 (SIK2) protein that phosphorylates the insulin receptor substrate 1 (IRS-1) protein at Ser794 and subsequently causes insulin resistance ${ }^{28,29}$ was also found on this list of proteins and was one of only two proteins significantly increased in binding versus total protein (Figure 2 and Supplemental Table 1) in both rosiglitazone and pioglitazone elutions.

\section{DISCUSSION AND CONCLUSIONS}

The two main goals of this study were first to develop a unique two-phase selection technique for assessing pharmaceutical off-target protein binding and secondly, to compare similarities and differences between the off-target protein binding profiles for rosiglitazone and pioglitazone, providing clues for assessing cardiotoxicity. To achieve these goals, proteins from rat heart homogenates were selected for through interaction with a glitazone privileged scaffold and eluted using high salt, glitazone, rosiglitazone, or pioglitazone, followed by subsequent identification via LC-MS/MS analysis. Using sophisticated computational analysis of identified proteins ${ }^{27}$, several findings emerged that provide 
insights into rosiglitazone and pioglitazone mechanistic action within the cardiovascular system, including implications for compounding drug efficacy and cardiotoxicity. First, the majority of heart proteins identified eluted with both rosiglitazone and pioglitazone, suggesting that they have a similar mechanistic action and similar potential for producing cardiotoxicity. Secondly, of the protein binding partners that were common between rosiglitazone and pioglitazone elutions from the glitazone scaffold, only a small subset were differentially eluted with one drug versus the other (Tables 2 and 3). Third, several common classes of proteins were identified in rosiglitazone and pioglitazone elutions off a glitazone scaffold that possess the potential for an increase in drug efficacy or adverse cardiovascular events. Some examples are ion channels and solute transporters, lipid metabolism proteins, and mitochondrial proteins involved in meeting the high energy demands of the heart. It is especially significant that ion channels, such as L-type calcium channels, were identified, as they play a central role in maintaining proper cardiac rhythms. Lastly, PPAR $\gamma$ elution off the glitazone scaffold was not detected in cardiac tissue, although it was detected in elutions from liver and adipose tissue homogenates at low levels. It is possible that off-target protein binding partners, in addition to PPAR $\gamma$, could contribute to TZD efficacy, especially since data on direct binding of TZDs to the receptor in complex mixtures is not well defined. In this regard, several other off-target binding partners were identified which indirectly or directly could affect the degree of insulin sensitivity.

Rosiglitazone and pioglitazone are thought to exert their primary therapeutic effects through binding to the peroxisome proliferator-activated receptor gamma (PPAR $\gamma$ ) in adipose tissue, in turn increasing sensitivity to insulin and producing better glycemic control ${ }^{4-6}$. It is clear from previous literature that thiazolidinediones can bind purified PPAR $\gamma^{4,6,7}$ and either directly or indirectly cause activation of the PPAR $\gamma$ pathway signaling as measured by activity assays ${ }^{5,30}$. The established targets of rosiglitazone and pioglitazone, PPAR $\gamma$ and PPAR $\delta$, were detected sporatically and at low scan counts in the tandem MS analysis of various elution conditions, however, not at levels that passed the stringent run count filters. This is not surprising, since the PPAR receptors are expressed only at low levels in the heart. However, rat liver (Supplemental Table 1) and adipose (data not shown) tissue homogenates did not exhibit high levels in elutions either, although they were identified as present. This low level of detection could be because: 1) transcription factors, such as PPAR $\gamma$, are present at very low levels - making detection particularly challenging, due to dynamic range limitations from more abundant proteins in the eluent, 2) PPAR is not binding the column (i.e. glitazone itself is not sufficient for binding or cofactors are required), 3) glitazone has higher affinity for other proteins in the complex protein homogenate compared to PPAR $\gamma$, or 4) PPAR $\gamma$ could be occupied with free lipid byproducts from the homogenization step preventing drug binding. Free LDL levels have been shown to increase in rat serum after administration of rosiglitazone ${ }^{20}$, which could also lead to increased PPAR $\gamma$ pathway activation. However, questions as to whether additional drug efficacy is achieved through receptor-independent off-target actions of TZDs remain, since it is possible that some drug efficacy could be attributed to binding to proteins in addition to PPAR $\gamma^{18,31}$.

Receptor-independent actions of rosiglitazone and pioglitazone have been reported in previous literature ${ }^{18,31}$ and this study has identified numerous off-target interacting proteins involved in mitochondrial function, lipid/fatty acid metabolism, and glycolysis/ 
gluconeogenesis regulation (Tables 1-4 and Supplemental Table 1). Previous literature has indicated that PPAR $\gamma$ antagonists and transcriptional/translational inhibitors do not abolish TZD effects ${ }^{18,32}$, suggesting there are additional effects contributing to increasing insulin sensitivity. A potential non-receptor candidate protein that has potential to directly affect insulin receptor-sensitivity, SIK2, was detected in this study for both TZDs tested (Supplemental Table 1). SIK2 is known to phosphorylate IRS-1 Ser794 rendering it inactive during nutrition deprivation, causing insulin-resistance ${ }^{28,29}$. A potential alternate hypothesis for increased insulin-sensitivity with application of rosiglitazone and pioglitazone could be that SIK2 binds to the drugs and IRS-1 Ser794 phosphorylation in adipocytes is inhibited, thus increasing insulin sensitivity. Additional receptor-independent off-target binding partners for the TZDs (Tables 1-5 and Supplemental Table 1), as indicated in this study, are involved in altering mitochondrial aerobic respiration, which in turn leads to changes in metabolism, energy production, and consequently insulin-sensitivity ${ }^{18,33-35}$. Pyruvate dehydrogenase, malate dehydrogenase, isocitrate dehydrogenase, Acetyl-CoA dehydrogenases, and citrate synthase are all part of the citric acid cycle proximal to complex I in the mitochondria and were detected to be individual or complex binding partners for TZDs. Previous studies suggest that TZD inhibition of complex I or proximal to the complex affect mitochondrial respiration and cause alterations in energy states, in turn increasing insulin-sensitizing effects ${ }^{18,33-35}$. Additionally, dehydrogenase enzymes have been shown to exhibit direct involvement in adipogenesis ${ }^{19}$.

While there were slight differences in the off-target binding profiles between rosiglitazone and pioglitazone, there were many more similarities in individual protein and pathway comparisons, suggesting that the drugs may operate through similar off-target mechanisms in terms of both efficacy and potential toxicity. Resulting off-target binding profiles of both rosiglitazone and pioglitazone show that the drugs both bind to mitochondrial respiratory chain proteins (Tables 1-4), as well as a large number of ion channels and solute transporters (Table 4) previously implicated in abnormal cardiovascular functions. Energy deprivation produced from inhibition of mitochondrial respiration has the potential to increase insulin sensitivity ${ }^{18,34}$, but could also lead to a lack in fulfilling the high energy demands of cardiac tissue. Not only were there TCA Cycle proteins bound to both pioglitazone and rosiglitazone, ATP synthase was also bound, which is crucial for utilizing the proton gradient from mitochondrial respiration to produce ATP energy for tissues. TZDs have been shown to cause mitochondrial dysfunction and decrease mitochondrial ATP production ${ }^{18,34,35}$. Deficiencies in mitochondrial ATP synthase can lead to hypertrophic cardiomyopathy ${ }^{36,37}$. Additionally, pioglitazone bound to phosphoglycerate kinase 1 , triosphosphate isomerase, and creatine kinase at significantly increased amounts compared with rosiglitazone; all are involved in providing energy for high energy demanding tissues.

TZD inhibition in the mitochondrial machinery can also lead to an increase in reactive oxygen species (ROS) through complex I inhibition ${ }^{38}$. TZD-induced depolarization of the mitochondria in astroglioma cells has been shown to increase ROS, which interacts with nitric oxide to form a cytoxic peroxynitrate ${ }^{38}$. Both rosiglitazone and pioglitazone bound numerous proteins involved in clearance of ROS. SODC and glutathione (GSH) levels have previously been shown to decrease, while catalase increased, in the serum of Wistar Rats after application of rosiglitazone or pioglitazone ${ }^{20}$. Besides SODC and catalase, bound to 
both drugs was the selenocysteine insertion sequence binding protein 2 (SEPB2) (Table 3), which adds the essential trace element selenium to the reactive site of GSH peroxidase (GPx) and is required for its function. Mutations in SEPB2 exhibit a similar phenotype to GPx mutants and lead to an increase in ROS production, which coincidently leads to an increase in insulin sensitivity ${ }^{39}$. While SOD did not appear functionally affected in activity assays following treatment with both drugs (data not shown), the potential build up of ROS in relation to alterations in any of these key points of regulation within the ROS pathway could lead to cardiotoxicity, possibly through an oxidase-independent mechanism ${ }^{38}$.

In addition to channels like ATP synthase, numerous ion channels or amine transporters were bound to the TZDs and dysfunction in regulation could affect frequency and force of heart tissue contractions resulting in arrhythmia, heart attack, or even peripheral edema and congestive heart failure. Proteins detected as 'top-hits' for rosiglitazone and pioglitazone elutions included the voltage-dependent L-type calcium channel (CAC1F), chloride channel protein 6 (CLCN-6), neutral amino acid transporters, and membrane transport protein XK (XK). Disruption of the L-type calcium channel could be beneficial but certainly affects cardiac rhythym and under persistent alterations in activity could be a source of cardiotoxicity. Importantly, there have been reports that thiazolidinediones can directly interact with and affect L-type calcium channels ${ }^{24-26,40-42}$, thereby validating our findings that suggest drug binding to L-type calcium. Numerous other sodium, potassium, chloride, and amine transporters detected in this study have also been shown to exhibit regulation of action potential and membrane polarization by various TZDs ${ }^{21-23,25,43-47}$. A distinct network of excitatory synaptic transduction regulating proteins were also detected and could potentially have similar adverse effects on the heart and cardiovascular system (Table 5), but via the the sympathetic system.

While previous literature clearly suggests that rosiglitazone increases the risk of adverse cardiac-related events ${ }^{10,11}$, our data would suggest that pioglitazone is very similar in terms of the rat heart binding profiles. These profiles identify potential direct sources contributing to both efficacy and cardiotoxicity via perturbations in mitochondrial function, cardiac ion channels (ex. L-type calcium channels), and disruption of the cardiac sympathetic signaling. While rosiglitazone and pioglitazone off-target protein binding profiles are very similar in composition, there is the chance for variance in effects based on affinity for the particular protein leading to slight differences in efficacy or cytotoxicity $46,48-50$. Additionally, it is recognized that long-term dosing of an animal model with rosiglitazone or pioglitazone may lead to increased levels of additional off-target binding partners and that indirect effects could contribute to efficacy and cardiotoxicity. One must also keep in mind that patients taking these drugs are also the severe type II diabetic patients for whom other forms of regulation are not therapeutically effective and their cardiovascular system is already severely impaired making them high risk, which could also be a contributing factor. There is also literature that suggests adverse events could be dependent on age and increasing cardiotoxicity in elderly patients ${ }^{11,15}$.

The techniques presented herein, which provide a comparison of binding profiles as chemical structures of drugs are varied, could also be used to make additional improvements to existing drugs, or to find existing drugs with similar elution profiles. Once proteins 
associated with potential for adverse effects are identified, the core scaffold can be systematically modified to tune the binding profile in such a way as to avoid binding to undesired proteins, as described previously ${ }^{17}$. The latter application suggests utility in repurposing drugs, to identify drugs with desirable off-target binding profiles; if one elutes from a column containing a core from one drug, using a second drug that is thought to operate by a different mechanism but actually may bind similar proteins. Experimental approaches such as this are the subject of ongoing studies in our laboratories and provide invaluable information to decipher both beneficial and cytotoxic interactions of drugs.

\section{EXPERIMENTAL METHODS}

\section{Coupling of glitazone to the epoxy resin}

Epoxide resin $(1.5 \mathrm{~g})$ was incubated in phosphate buffer solution $\left(\mathrm{Na}_{2} \mathrm{HPO}_{4} \& \mathrm{KH}_{2} \mathrm{PO}_{4}\right)$ at $\mathrm{pH} 10$ for 3 hours. Then $0.8 \mathrm{~g} \mathrm{~K}_{2} \mathrm{CO}_{3}$ and $1.9 \mathrm{~g}$ of glitazone were added, followed by gentle aggitation for 3 days at room temperature. p-cresol, potassium carbonate, potassium phosphate (monobasic), sodium phosphate (dibasic) and an epoxide functionalized resin (ca $2 \mathrm{mmol} / \mathrm{g}$ ) were from Alfa Aesar and 5-(4-hydroxybenzyl)-1,3-thiazolidine-2,4-dione (glitazone; $\geq 97 \%$ purity as determined by HPLC) was from Accela ChemBio Inc. IR spectra were collected on a Nicolet $560 \mathrm{FT}-\mathrm{IR}$ spectrometer, in a $\mathrm{KBr}$ pellet, to confirm coupling. In the same manner, a control column was prepared by coupling with $1.6 \mathrm{~g}$ of p-cresol (Alfa Aesar) in place of glitazone.

\section{Preparation of rat heart and liver homogenates}

Sprague Dawley rats of 8-10 weeks of age on a $4 \% \mathrm{NaCl}$ diet were sacrificed using $0.3 \mathrm{~mL}$ of Beuthenasia. Hearts and livers were excised and quartered into $2 \mathrm{~mL}$ microcentrifuge tubes followed by liquid nitrogen snap freezing. $5 \mathrm{~mm}$ stainless steel beads (Qiagen, cat. \#69989) were added to each tube for bead homogenization along with $1 \mathrm{~mL}$ of low salt $1 \mathrm{X}$ TBS, pH 7.8. A Tissue Lyser II was used at $20 \mathrm{~Hz}$ frequency for 90 seconds three times and $30 \mathrm{~Hz}$ for 120 seconds two times to generate crude homogenates for heart and liver samples. Crude homogenates were centrifuged at $3,500 \times \mathrm{g}(4600 \mathrm{rpm})$ for 15 minutes at $4{ }^{\circ} \mathrm{C}$ for removal of high molecular weight debris. Supernatants were transferred to $2 \mathrm{~mL}$ Beckman centrifuge tubes, balanced, and underwent ultra-centrifugation for 30 minutes at 100,000 $\times \mathrm{g}$ $(55,000 \mathrm{rpm})$ at $4^{\circ} \mathrm{C}$. Supernatants were transferred to a fresh tube and microsomal pellets were resuspended in $0.5-1.0 \mathrm{~mL}$ of low salt $1 \mathrm{X}$ TBS, $\mathrm{pH} 7.8$, depending on the pellet size. MicroBCA Assay (BioRAD) was then performed on the soluble and microsomal protein fractions, while the remaining protein mixtures were snap frozen and stored at $-80^{\circ} \mathrm{C}$ for future use.

\section{Eluting rat heart protein using glitazone}

Both the glitazone and control columns were equilibrated in Buffer A (low salt TBS: $25 \mathrm{mM}$ Tris- $\mathrm{HCl}, 50 \mathrm{mM} \mathrm{NaCl}, \mathrm{pH} 7.8$ ), then $0.5 \mathrm{mg}$ of protein sample (either soluble or membrane fraction) was loaded onto the columns, and incubated for 15 minutes. Then both columns were washed with Buffer A (10-15 bed volumes), and flow-through was saved. Columns were eluted using Buffer B (2 mM glitazone in Buffer A) and fractions were collected. 
Columns were flushed using high salt TBS buffer $(1 \mathrm{M} \mathrm{NaCl}, 10 \mathrm{mM}$ Tris, $\mathrm{pH}=7.8)$ then reequilibrated with 20 bed volumes of buffer A.

\section{Eluting rat liver protein using rosiglitazone and pioglitazone}

The glitazone column was equilibrated in low salt TBS (25mM Tris- $\mathrm{HCl}, 50 \mathrm{mM} \mathrm{NaCl}, \mathrm{pH}$ 7.8 , then $0.5 \mathrm{mg}$ of protein sample (either soluble or membrane fraction) was loaded onto the column, and incubated for 15 minutes. Then the column was washed with Buffer A (1015 bed volumes), and flow through was saved. Column was eluted with Buffer B (50 or 500 $\mu \mathrm{M}$ rosiglitazone or pioglitazone in Buffer $\mathrm{A}$ ) and fractions were collected. Columns were flushed using high salt TBS ( $1 \mathrm{M} \mathrm{NaCl}, 10 \mathrm{mM}$ Tris), pH 6.8 and re-equilibrated with buffer A. 5-[[4-[2-(5-Ethyl-2-pyridinyl)ethoxy]phenyl]methyl]-2,4-thiazolidinedione hydrochloride (Pioglitazone or Actos) was from Sigma-Aldrich and 5-(4-(2-(methyl(pyridin-2yl)amino)ethoxy)benzyl)thiazolidine-2,4-dione (Rosiglitazone or Avandia) was from Cayman Chemical Company. Both rosiglitazone and pioglitazone were $\geq 98 \%$ purity as determined by HPLC.

\section{Preparation of samples for mass spectral analysis}

Buffer exchange into $50 \mathrm{mM}$ ammonium bicarbonate was performed using Amicon Ultra-15 Ultracel Centrifugal filters with a 3,000-Da molecular weight cut-off (Millipore, Billerica, MA) using four 20 minute cycles at 3,500 $\times \mathrm{g}$. Samples were dried using a vacuum centrifuge and resuspended in $100 \mu \mathrm{L} 50 \mathrm{mM}$ ammonium bicarbonate. Protein samples were then reduced with $10 \mathrm{mM}$ dithiothreitol at $56^{\circ} \mathrm{C}$ for 30 minutes, cooled to room temperature, alkylated with $20 \mathrm{mM}$ iodoacetamide for 30 minutes in the dark, and digested using $0.5 \mu \mathrm{g}$ sequencing grade trypsin (Promega) overnight $\left(\sim 16\right.$ hours) at $37^{\circ} \mathrm{C}$. Peptide mixtures were acidified ( $\sim \mathrm{pH} 4$ ) and Varian Omix C18 desalting tips (Agilent Technologies, Santa Clara, CA) were used to clean and elute peptides. Desalted peptides were dried using a vacuum centrifuge and re-suspended in 98\%HPLC water/2\% ACN/0.1\% Formic acid.

\section{Liquid chromatography and mass spectrometry}

Tryptic peptide mixtures $(1.9 \mu \mathrm{l})$ were injected via a NanoAccuity UPLC system (Waters, Milford, MA) and passed over an in-house packed C18 resin (Phenomenex, Torrance, CA) column (10 cm long 50 $\mu \mathrm{m}$ inner diameter). A gradual gradient from 98\% HPLC water $/ 2 \%$ ACN/0.1\% Formic acid to 98\% ACN/2\% HPLC water/0.1\% Formic acid was applied to peptide mixtures. As peptides eluted they were analyzed using an Orbitrap Velos mass spectrometer (Thermo Scientific, Waltham, MA). Initial parent ion scans (MS1) were performed in the FTMS portion with $10^{6}$ ions collected over a maximum accumulation time of $500 \mathrm{~ms}$ and a resolution of 30,000 at full width of a spectral peak at half-maximum peak height (FWHM at $400 \mathrm{~m} / \mathrm{z}$ ). The 10 most abundant ions selected for collision induced dissociation fragmentation (MS/MS) in the LTQ ion trap portion of the instrument with an ion intensity threshold of 500 and a normalized collision energy of 35\%. Ten thousand ions were collected from fragmentation spectra over a maximum accumulation time of $25 \mathrm{~ms}$. Dynamic exclusion was used, excluding any given mass observed more than once in a 30 second time frame for 180 seconds from selection for fragmentation. 


\section{Supplementary Material}

Refer to Web version on PubMed Central for supplementary material.

\section{Acknowledgments}

This work was supported in part by NIH grant GM085739 to DSS, as well as by the Biotechnology and Bioengineering and Innovation Centers at the Medical College of Wisconsin. The project described was also supported by Grant Number T32HL094273 to BRH from the National Heart, Lung, And Blood Institute.

\section{Abbreviation List}

$\begin{array}{ll}\text { LTQ } & \text { Linear Trap Quadrupole } \\ \text { TZD } & \text { thiazolidinedione } \\ \text { SOD } & \text { superoxide dismutase } \\ \text { SIK2 } & \text { salt-inducible kinase } 2 \\ \text { IRS-1 } & \text { insulin receptor substrate } 1 \\ \text { CLCN-6 } & \text { chloride channel protein } 6 \\ \text { CAC1F } & \text { voltage-dependent L-type calcium channel } \\ \text { SEPB2 } & \text { selenocysteine insertion sequence binding protein 2 } \\ \text { GSH } & \text { glutathione } \\ \text { GPx } & \text { glutathione peroxidase }\end{array}$

\section{References}

1. Smith MT. Mechanisms of troglitazone hepatotoxicity. Chem Res Toxicol. 2003; 16(6):679-687. [PubMed: 12807350]

2. Beiderbeck AB, Sakaguchi M. Commentary on 'Case series of liver failure associated with rosiglitazone and pioglitazone' by James Floyd et al. Pharmacoepidemiol Drug Saf. 2009; 18(12): 1247-1249. [PubMed: 19842093]

3. Osei SY, Koro CE, Cobitz AR, Kolatkar NS, Stender M. Commentary on 'Case series of liver failure associated with rosiglitazone and pioglitazone' by Floyd et al. Pharmacoepidemiol Drug Saf. 2009; 18(12):1244-1246. [PubMed: 19655316]

4. Chandra V, Huang P, Hamuro Y, Raghuram S, Wang Y, Burris TP, Rastinejad F. Structure of the intact PPAR-gamma-RXR- nuclear receptor complex on DNA. Nature. 2008; 456(7220):350-356. [PubMed: 19043829]

5. Forman BM, Tontonoz P, Chen J, Brun RP, Spiegelman BM, Evans RM. 15-Deoxy-delta 12, 14prostaglandin $\mathrm{J} 2$ is a ligand for the adipocyte determination factor PPAR gamma. Cell. 1995; 83(5): 803-812. [PubMed: 8521497]

6. Lehmann JM, Moore LB, Smith-Oliver TA, Wilkison WO, Willson TM, Kliewer SA. An antidiabetic thiazolidinedione is a high affinity ligand for peroxisome proliferator-activated receptor gamma(PPAR gamma). J Biol Chem. 1995; 270(22):12953-12956. [PubMed: 7768881]

7. Young PW, Buckle DR, Cantello BC, Chapman H, Clapham JC, Coyle PJ, Haigh D, Hindley RM, Holder JC, Kallender H, Latter AJ, Lawrie KW, Mossakowska D, Murphy GJ, Roxbee Cox L, Smith SA. Identification of high-affinity binding sites for the insulin sensitizer rosiglitazone (BRL-49653) in rodent and human adipocytes using a radioiodinated ligand for peroxisomal proliferator-activated receptor gamma. J Pharmacol Exp Ther. 1998; 284(2):751-759. [PubMed: 9454824] 
8. Berlie HD, Kalus JS, Jaber LA. Thiazolidinediones and the risk of edema: a meta-analysis. Diabetes Res Clin Pract. 2007; 76(2):279-289. [PubMed: 17055103]

9. Cekmen N, Cesur M, Cetinbas R, Bedel P, Erdemli O. Acute pulmonary edema due to rosiglitazone use in a patient with diabetes mellitus. J Intensive Care Med. 2006; 21(1):47-50. [PubMed: 16698744]

10. Nissen SE, Wolski K. Effect of rosiglitazone on the risk of myocardial infarction and death from cardiovascular causes. N Engl J Med. 2007; 356(24):2457-2471. [PubMed: 17517853]

11. Graham DJ, Ouellet-Hellstrom R, MaCurdy TE, Ali F, Sholley C, Worrall C, Kelman JA. Risk of acute myocardial infarction, stroke, heart failure, and death in elderly Medicare patients treated with rosiglitazone or pioglitazone. JAMA. 2010; 304(4):411-418. [PubMed: 20584880]

12. Loke YK, Kwok CS, Singh S. Comparative cardiovascular effects of thiazolidinediones: systematic review and meta-analysis of observational studies. BMJ. 2011; 342:d1309. [PubMed: 21415101]

13. Nesto RW, Bell D, Bonow RO, Fonseca V, Grundy SM, Horton ES, Le Winter M, Porte D, Semenkovich CF, Smith S, Young LH, Kahn R. Thiazolidinedione use, fluid retention, and congestive heart failure: a consensus statement from the American Heart Association and American Diabetes Association. Diabetes Care. 2004; 27(1):256-263. [PubMed: 14693998]

14. Diamond GA, Kaul S. Rosiglitazone and cardiovascular risk. N Engl J Med. 2007; 357(9):938939. author reply 939-940. [PubMed: 17806135]

15. Wertz DA, Chang CL, Sarawate CA, Willey VJ, Cziraky MJ, Bohn RL. Risk of cardiovascular events and all-cause mortality in patients treated with thiazolidinediones in a managed-care population. Circ Cardiovasc Qual Outcomes. 2010; 3(5):538-545. [PubMed: 20736441]

16. Diamond GA, Bax L, Kaul S. Uncertain effects of rosiglitazone on the risk for myocardial infarction and cardiovascular death. Ann Intern Med. 2007; 147(8):578-581. [PubMed: 17679700]

17. Ge X, Wakim B, Sem DS. Chemical proteomics-based drug design: target and antitarget fishing with a catechol-rhodanine privileged scaffold for $\mathrm{NAD}(\mathrm{P})(\mathrm{H})$ binding proteins. J Med Chem. 2008; 51(15):4571-4580. [PubMed: 18616236]

18. Feinstein DL, Spagnolo A, Akar C, Weinberg G, Murphy P, Gavrilyuk V, Dello Russo C. Receptor-independent actions of PPAR thiazolidinedione agonists: is mitochondrial function the key? Biochem Pharmacol. 2005; 70(2):177-188. [PubMed: 15925327]

19. Liu Y, Park F, Pietrusz JL, Jia G, Singh RJ, Netzel BC, Liang M. Suppression of 11 betahydroxysteroid dehydrogenase type 1 with RNA interference substantially attenuates 3T3-L1 adipogenesis. Physiol Genomics. 2008; 32(3):343-351. [PubMed: 18073273]

20. Saraogi P, Pillai KK, Singh BK, Dubey K. Rosiglitazone and pioglitazone aggravate doxorubicininduced cardiomyopathy in Wistar rats. Biomed Pharmacother. 2010

21. Hancox JC. Cardiac ion channel modulation by the hypoglycaemic agent rosiglitazone. $\mathrm{Br} \mathrm{J}$ Pharmacol. 2011; 163(3):496-498. [PubMed: 21561443]

22. Heo KS, Ryoo SW, Kim L, Nam M, Baek ST, Lee H, Lee AR, Park SK, Park Y, Myung CS, Kim DU, Hoe KL. Cl- -channel is essential for LDL-induced cell proliferation via the activation of Erk1/2 and PI3k/Akt and the upregulation of Egr-1 in human aortic smooth muscle cells. Mol Cells. 2008; 26(5):468-473. [PubMed: 18711316]

23. Lu L, Reiter MJ, Xu Y, Chicco A, Greyson CR, Schwartz GG. Thiazolidinedione drugs block cardiac KATP channels and may increase propensity for ischaemic ventricular fibrillation in pigs. Diabetologia. 2008; 51(4):675-685. [PubMed: 18251006]

24. Nakajima T, Iwasawa K, Oonuma H, Imuta H, Hazama H, Asano M, Morita T, Nakamura F, Suzuki J, Suzuki S, Kawakami Y, Omata M, Okuda Y. Troglitazone inhibits voltage-dependent calcium currents in guinea pig cardiac myocytes. Circulation. 1999; 99(22):2942-2950. [PubMed: 10359740]

25. Szentandrassy N, Harmati G, Barandi L, Simko J, Horvath B, Magyar J, Banyasz T, Lorincz I, Szebeni A, Kecskemeti V, Nanasi PP. Effects of rosiglitazone on the configuration of action potentials and ion currents in canine ventricular cells. Br J Pharmacol. 2011; 163(3):499-509. [PubMed: 21232044]

26. Zhang F, Sowers JR, Ram JL, Standley PR, Peuler JD. Effects of pioglitazone on calcium channels in vascular smooth muscle. Hypertension. 1994; 24(2):170-175. [PubMed: 8039840] 
27. Halligan BD, Greene AS. Visualize: a free and open source multifunction tool for proteomics data analysis. Proteomics. 2011; 11(6):1058-1063. [PubMed: 21365761]

28. Horike N, Takemori H, Katoh Y, Doi J, Min L, Asano T, Sun XJ, Yamamoto H, Kasayama S, Muraoka M, Nonaka Y, Okamoto M. Adipose-specific expression, phosphorylation of Ser794 in insulin receptor substrate-1, and activation in diabetic animals of salt-inducible kinase-2. J Biol Chem. 2003; 278(20):18440-18447. [PubMed: 12624099]

29. Du J, Chen Q, Takemori H, Xu H. SIK2 can be activated by deprivation of nutrition and it inhibits expression of lipogenic genes in adipocytes. Obesity (Silver Spring). 2008; 16(3):531-538. [PubMed: 18239551]

30. Li YT, Li L, Chen J, Hu TC, Huang J, Guo YW, Jiang HL, Shen X. 7-Chloroarctinone-b as a new selective PPARgamma antagonist potently blocks adipocyte differentiation. Acta Pharmacol Sin. 2009; 30(9):1351-1358. [PubMed: 19684608]

31. Higashi Y, Holder K, Delafontaine P. Thiazolidinediones up-regulate insulin-like growth factor-1 receptor via a peroxisome proliferator-activated receptor gamma-independent pathway. J Biol Chem. 2010; 285(47):36361-36368. [PubMed: 20843793]

32. Lea MA, Sura M, Desbordes C. Inhibition of cell proliferation by potential peroxisome proliferator-activated receptor(PPAR) gamma agonists and antagonists. Anticancer Res. 2004; 24(5A):2765-2771. [PubMed: 15517883]

33. Dello Russo C, Gavrilyuk V, Weinberg G, Almeida A, Bolanos JP, Palmer J, Pelligrino D, Galea E, Feinstein DL. Peroxisome proliferator-activated receptor gamma thiazolidinedione agonists increase glucose metabolism in astrocytes. J Biol Chem. 2003; 278(8):5828-5836. [PubMed: 12486128]

34. Brunmair B, Staniek K, Gras F, Scharf N, Althaym A, Clara R, Roden M, Gnaiger E, Nohl H, Waldhausl W, Furnsinn C. Thiazolidinediones, like metformin, inhibit respiratory complex I: a common mechanism contributing to their antidiabetic actions? Diabetes. 2004; 53(4):1052-1059. [PubMed: 15047621]

35. Scatena R, Bottoni P, Martorana GE, Ferrari F, De Sole P, Rossi C, Giardina B. Mitochondrial respiratory chain dysfunction, a non-receptor-mediated effect of synthetic PPAR-ligands: biochemical and pharmacological implications. Biochem Biophys Res Commun. 2004; 319(3): 967-973. [PubMed: 15184076]

36. Das AM. Regulation of mitochondrial ATP synthase activity in human myocardium. Clin Sci(Lond). 1998; 94(5):499-504. [PubMed: 9682672]

37. Sperl W, Jesina P, Zeman J, Mayr JA, Demeirleir L, VanCoster R, Pickova A, Hansikova H, Houst'kova H, Krejcik Z, Koch J, Smet J, Muss W, Holme E, Houstek J. Deficiency of mitochondrial ATP synthase of nuclear genetic origin. Neuromuscul Disord. 2006; 16(12):821829. [PubMed: 17052906]

38. Perez-Ortiz JM, Tranque P, Burgos M, Vaquero CF, Llopis J. Glitazones induce astroglioma cell death by releasing reactive oxygen species from mitochondria: modulation of cytotoxicity by nitric oxide. Mol Pharmacol. 2007; 72(2):407-417. [PubMed: 17504946]

39. Schoenmakers E, Agostini M, Mitchell C, Schoenmakers N, Papp L, Rajanayagam O, Padidela R, Ceron-Gutierrez L, Doffinger R, Prevosto C, Luan J, Montano S, Lu J, Castanet M, Clemons N, Groeneveld M, Castets P, Karbaschi M, Aitken S, Dixon A, Williams J, Campi I, Blount M, Burton H, Muntoni F, O'Donovan D, Dean A, Warren A, Brierley C, Baguley D, Guicheney P, Fitzgerald R, Coles A, Gaston H, Todd P, Holmgren A, Khanna KK, Cooke M, Semple R, Halsall D, Wareham N, Schwabe J, Grasso L, Beck-Peccoz P, Ogunko A, Dattani M, Gurnell M, Chatterjee K. Mutations in the selenocysteine insertion sequence-binding protein 2 gene lead to a multisystem selenoprotein deficiency disorder in humans. J Clin Invest. 2010; 120(12):4220-4235. [PubMed: 21084748]

40. Heppner TJ, Bonev AD, Eckman DM, Gomez MF, Petkov GV, Nelson MT. Novel PPARgamma agonists GI 262570, GW 7845, GW 1929, and pioglitazone decrease calcium channel function and myogenic tone in rat mesenteric arteries. Pharmacology. 2005; 73(1):15-22. [PubMed: 15452359]

41. Knock GA, Mishra SK, Aaronson PI. Differential effects of insulin-sensitizers troglitazone and rosiglitazone on ion currents in rat vascular myocytes. Eur J Pharmacol. 1999; 368(1):103-109. [PubMed: 10096775] 
42. Asano M, Nakajima T, Iwasawa K, Morita T, Nakamura F, Imuta H, Chisaki K, Yamada N, Omata M, Okuda Y. Troglitazone and pioglitazone attenuate agonist-dependent $\mathrm{Ca} 2+$ mobilization and cell proliferation in vascular smooth muscle cells. Br J Pharmacol. 1999; 128(3):673-683. [PubMed: 10516648]

43. Rusinova R, Herold KF, Sanford RL, Greathouse DV, Hemmings HC Jr, Andersen OS. Thiazolidinedione insulin sensitizers alter lipid bilayer properties and voltage-dependent sodium channel function: implications for drug discovery. J Gen Physiol. 2011; 138(2):249-270. [PubMed: 21788612]

44. Bajwa PJ, Lee JW, Straus DS, Lytle C. Activation of PPARgamma by rosiglitazone attenuates intestinal Cl- secretion. Am J Physiol Gastrointest Liver Physiol. 2009; 297(1):G82-89. [PubMed: 19443733]

45. Jeong I, Choi BH, Hahn SJ. Rosiglitazone inhibits Kv4. 3 potassium channels by open-channel block and acceleration of closed-state inactivation. Br J Pharmacol. 2011; 163(3):510-520. [PubMed: 21232039]

46. Eto K, Ohya Y, Nakamura Y, Abe I, Fujishima M. Comparative actions of insulin sensitizers on ion channels in vascular smooth muscle. Eur J Pharmacol. 2001; 423(1):1-7. [PubMed: 11438300]

47. Song J, Knepper MA, Hu X, Verbalis JG, Ecelbarger CA. Rosiglitazone activates renal sodiumand water-reabsorptive pathways and lowers blood pressure in normal rats. J Pharmacol Exp Ther. 2004; 308(2):426-433. [PubMed: 14593089]

48. Rabol R, Boushel R, Almdal T, Hansen CN, Ploug T, Haugaard SB, Prats C, Madsbad S, Dela F. Opposite effects of pioglitazone and rosiglitazone on mitochondrial respiration in skeletal muscle of patients with type 2 diabetes. Diabetes Obes Metab. 2010; 12(9):806-814. [PubMed: 20649633]

49. Gutschi LM, Malcolm JC, Favreau CM, Ooi TC. Paradoxically decreased HDL-cholesterol levels associated with rosiglitazone therapy. Ann Pharmacother. 2006; 40(9):1672-1676. [PubMed: 16912247]

50. Hernandez AV, Usmani A, Rajamanickam A, Moheet A. Thiazolidinediones and risk of heart failure in patients with or at high risk of type 2 diabetes mellitus: a meta-analysis and metaregression analysis of placebo-controlled randomized clinical trials. Am J Cardiovasc Drugs. 2011; 11(2):115-128. [PubMed: 21294599] 


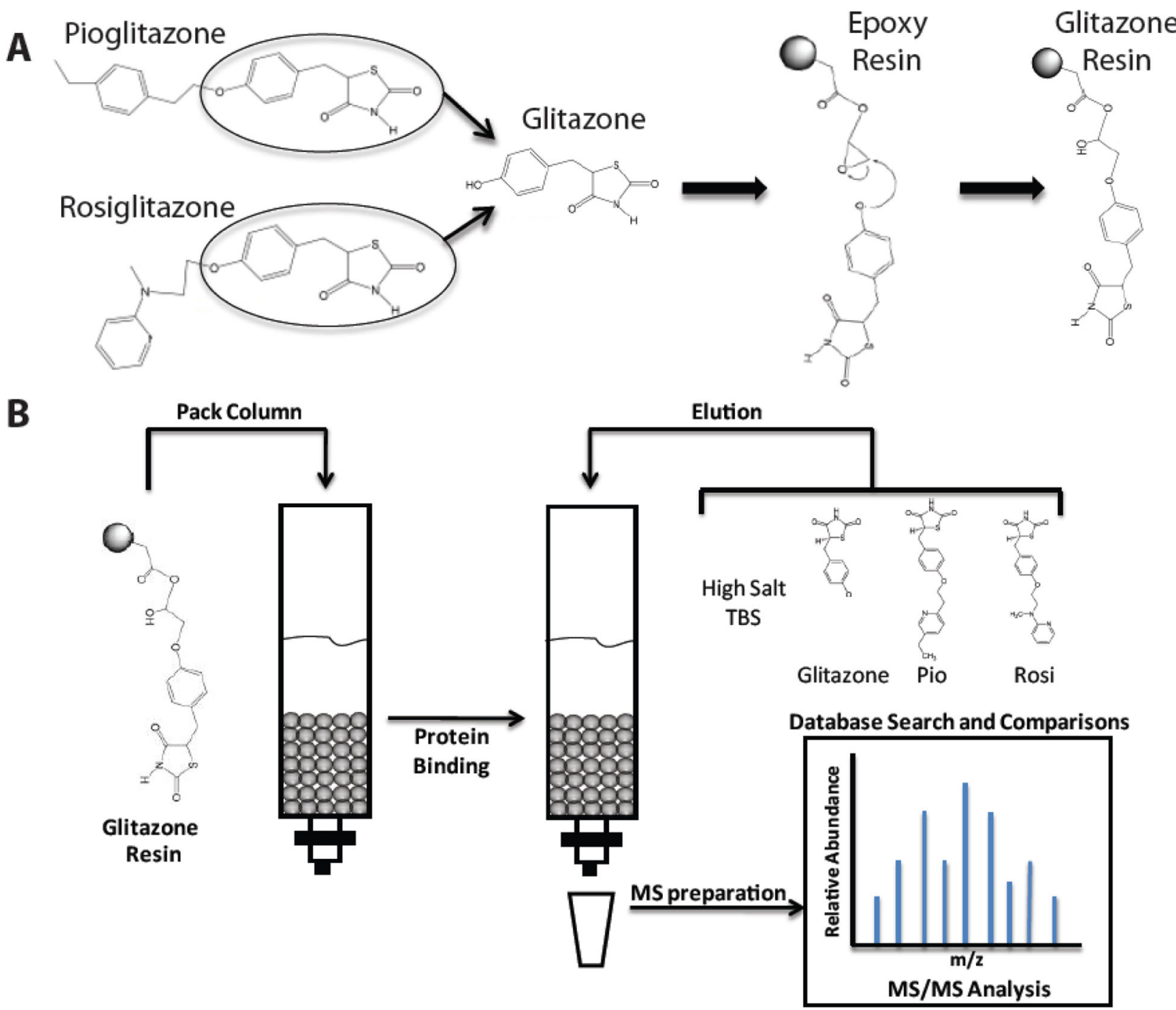

Figure 1.

Comparison of rosiglitazone and pioglitazone structures, (A) showing the shared glitazone core (privileged scaffold) used to construct the affinity column for purification of proteins that bind the glitazone core. Under basic conditions, epoxide resin was reacted with the phenoxide of glitazone, and production of the glitazone-derivatized resin was confirmed using IR spectroscopy (data not shown). (B) Proteins were then eluted with either rosiglitazone or pioglitazone, and elution profiles, analyzed using tandem mass spectrometry, were compared. 


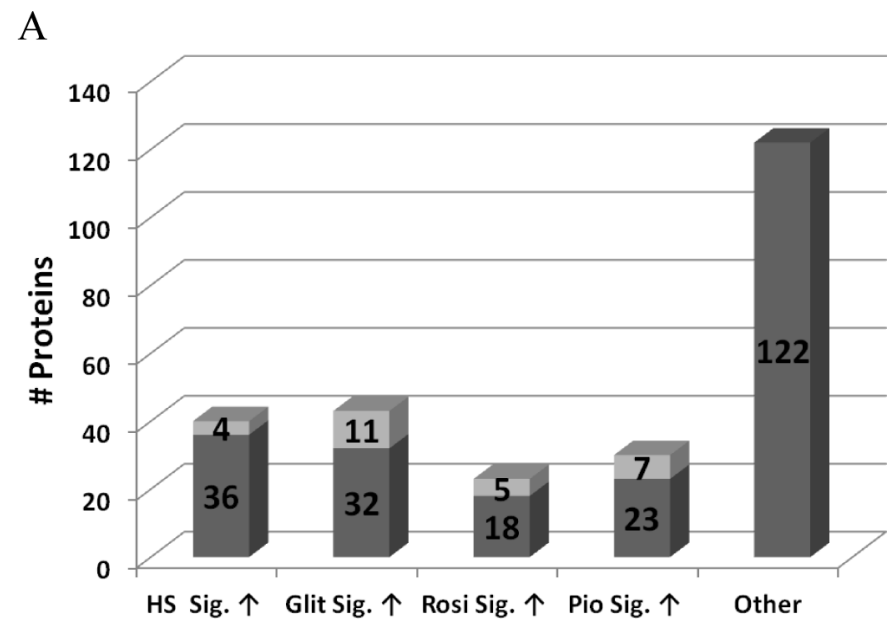

B

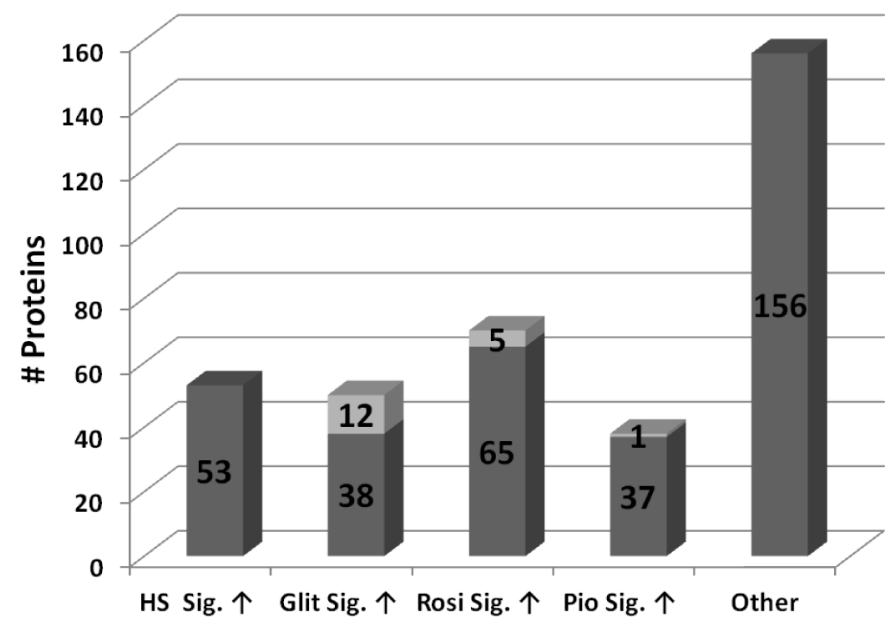

Figure 2.

Distribution of heart protein eluted off a phenol or glitazone scaffold, which showed a significant increase ( $\mathrm{p} \unlhd .05$ ) in abundance relative to total proteins eluted by all conditions (i.e. all detected proteins bound to the particular column). Elution conditions were compared, in terms of the total number of proteins bound then eluted from the affinity column. Total protein bound then eluted from the column is defined as proteins detected by tandem MS for all elution conditions combined and filtered. Numbers of proteins that showed a significant increase in levels after elutions using high salt TBS (non-specific) (HS), glitazone (Glit), rosiglitazone (Rosi), and pioglitazone (Pio) off of the (A) phenol scaffold and (B) glitazone scaffold are indicated. 
A

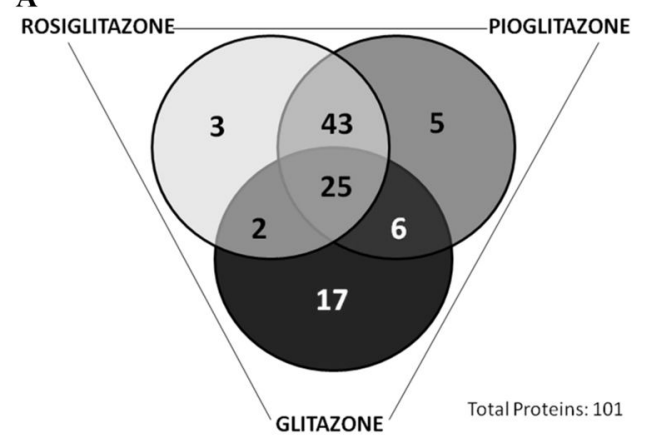

Figure 3.

Three-way comparison of proteins found in glitazone, rosiglitazone, and pioglitazone heart protein elutions off of affinity columns comprised of a phenol or glitazone scaffold. Each sphere represents a specific elution condition as indicated, and any overlap between spheres are proteins common to multiple conditions. (A) Comparison of glitazone, rosiglitazone, and pioglitazone elutions from a phenol scaffold and (B) from a glitazone scaffold are indicated. 


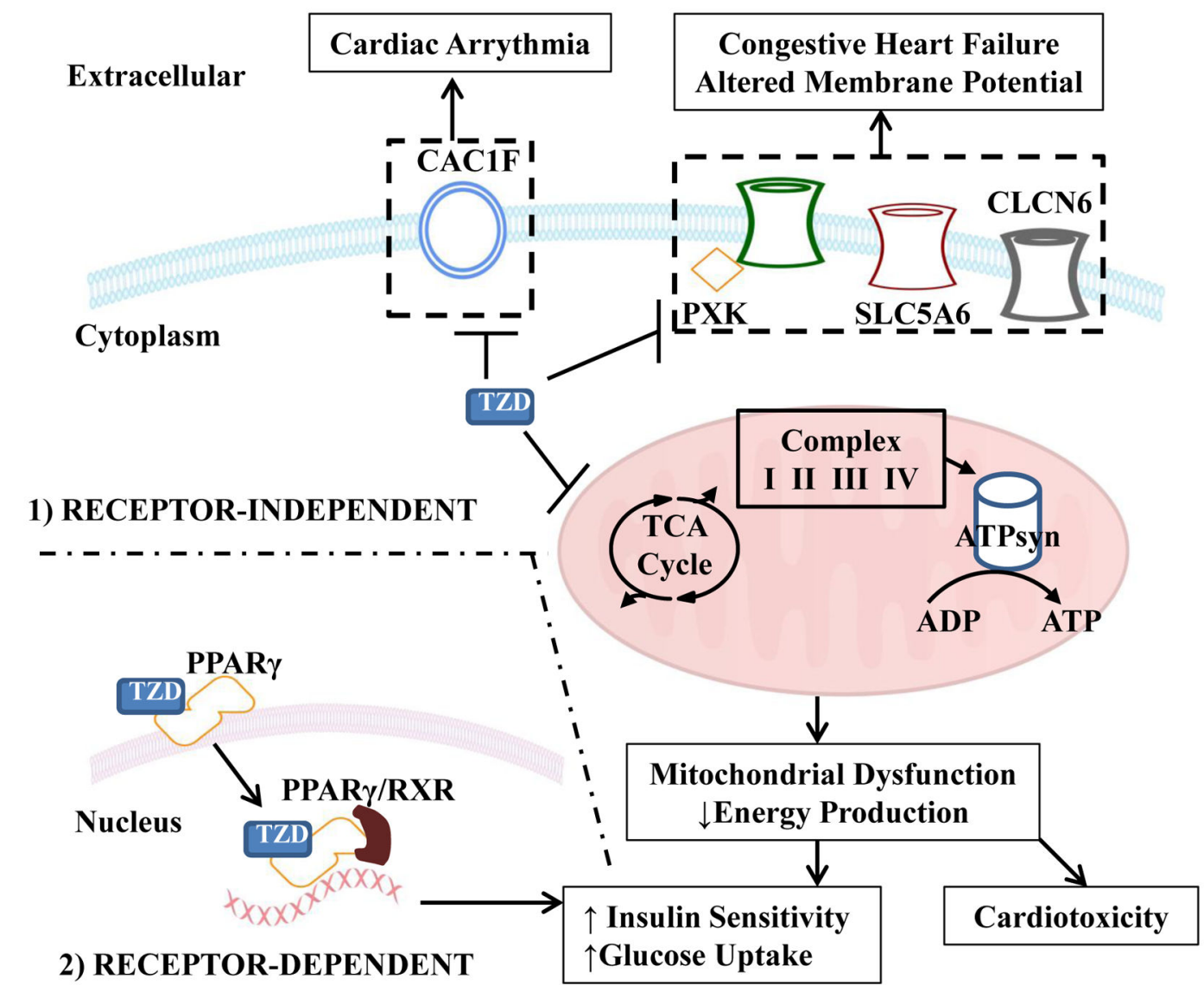

Figure 4.

Model summarizing rosiglitazone and pioglitazone 1) receptor-independent (off-target) interactions detected in this study and the 2) receptor-dependent interaction with PPAR $\gamma$ leading to increased insulin-sensitivity. Off-target interactions that potentially increase cardiotoxicity include effects on ion channels leading to cardiac arrhythmias, altered membrane potential, and congestive heart failure. Additionally, mitochondrial dysfunction would affect energy regulation in the heart, not only leading to cardiotoxicity, but also indirectly contributing to efficacy of the drugs. 


\section{Table 1}

Dehydrogenase enzymes with affinity for the thiazolidinedione in the glitazone scaffold.

\begin{tabular}{llccc}
\hline & & Glitazone & Rioglitazone & Pioglitazone \\
\cline { 3 - 5 } Accession \# & Description & Peps/Scans & Peps/Scans & Peps/Scans \\
\hline P15650 & Acyl-CoA dehydrogenase, long-chain specific, mitochondrial & $19 / 85$ & $4 / 10$ & $14 / 72$ \\
P04636 & Malate dehydrogenase, mitochondrial & $18 / 182$ & $3 / 11$ & - \\
P42123 & L-lactate dehydrogenase B chain & $16 / 57$ & $7 / 15$ & $11 / 32$ \\
P10860 & Glutamate dehydrogenase 1, mitochondrial & $15 / 28$ & - & - \\
P04797 & Glyceraldehyde-3-phosphate dehydrogenase & $14 / 48$ & $4 / 8$ & $6 / 15$ \\
Q60597 & 2-oxoglutarate dehydrogenase E1 component, mitochondrial & $14 / 27$ & - & $5 / 9$ \\
P45953 & Acyl-CoA dehydrogenase, very-long-chain specific, mitochondrial & $13 / 23$ & - & - \\
P54071 & Isocitrate dehydrogenase [NADP], mitochondrial & $11 / 23$ & - & - \\
P08503 & Acyl-CoA dehydrogenase, medium-chain specific, mitochondrial & $10 / 18$ & - & - \\
P14152 & Malate dehydrogenase, cytoplasmic & $9 / 23$ & $6 / 17$ & - \\
O08749 & Dihydrolipoyl dehydrogenase, mitochondrial & $8 / 19$ & $9 / 37$ & $10 / 69$ \\
P15651 & Acyl-CoA dehydrogenase, short-chain specific, mitochondrial & $6 / 9$ & - & - \\
P04642 & L-lactate dehydrogenase A chain & $7 / 19$ & - & - \\
P26284 & Pyruvate dehydrogenase E1 component a-subunit, mitochondrial & $6 / 11$ & - & - \\
Q9D2G2 & Dihydrolipoyllysine-residue succinyltransferase component of 2-oxoglutarate & $4 / 12$ & - & - \\
Q9WVK7 & Shydrogenase complex, mitochondrial & $3 / 12$ & - & - \\
\hline
\end{tabular}




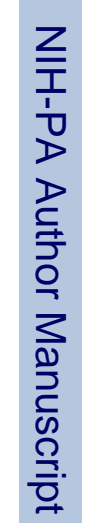

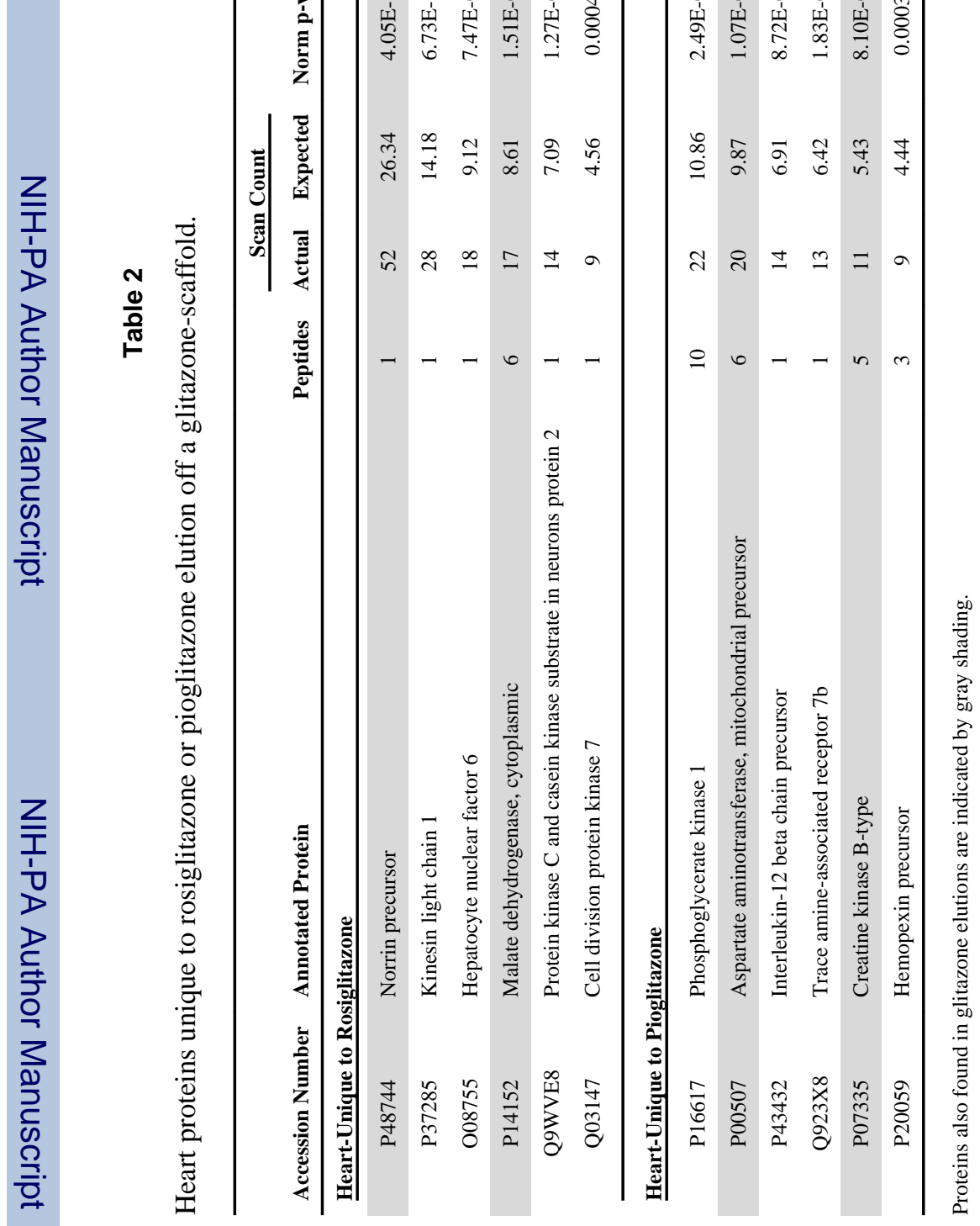

J Med Chem. Author manuscript; available in PMC 2014 July 28. 


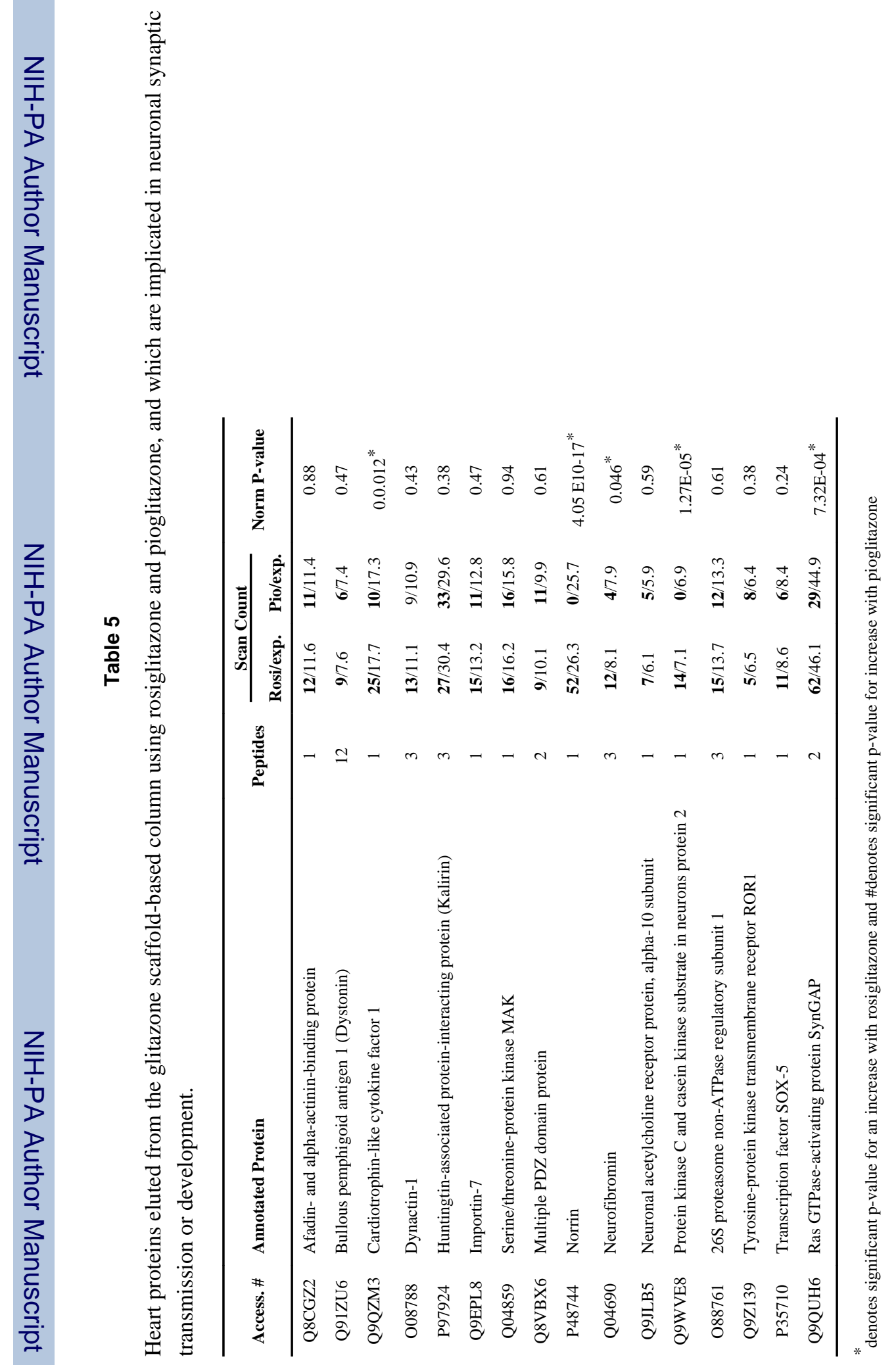

